\title{
Uji Pengolahan Limbah Cair Domestik Melalui Metode Koagulasi-Flokulasi dan Fitoremidiasi dengan Tanaman Kayu Apu (Pistia stratiotes L.)
}

\author{
Mimatun Nasihah ${ }^{1)}$, Anggreani Ayu Saraswati ${ }^{2)}$, Sayyidatn Najah ${ }^{3)}$ \\ ${ }^{1)}$ Dosen Program Studi Kesehatan Lingkungan Universitas Islam Lamongan \\ ${ }^{2,3)}$ Mahasiswa Program Studi Kesehatan Lingkungan Universitas Islam Lamongan \\ mima@unisla.ac.id, anggreanisaras@gmail.com
}

\begin{abstract}
ABSTRAK
Warga Desa Ketapangtelu sudah memiliki saluran air buangan untuk limbah cair domestik tapi tidak menggunakan dengan semestinya. Mereka lebih memilih membuang air limbah domestik ke sungai karena menurut mereka lebih efisien.Kebiasaan masyarakat tersebut yang belum mengerti akan pentingnya dampak dan bahaya yang ditimbulkan oleh limbah cair domestik tersebut. Limbah cair domestik merupakan air buangan yang berasal dari kegiatan rumah tangga yang jika langsung dibuang ke lingkungan tanpa ada pengolahan terlebih dahulu akan menyebabkan pencemaran lingkungan dan merusak biota air. Salah satu upaya dalam mengelola limbah domestik yaitu dengan pengolahan koagulasi-flokulasi dan fitoremidiasi menggunakan tanaman kayu apu (Pistiastratiotes L.) dan bahan pendukung lainnya seperti kerikil dan pasir. Metode yang digunakan adalah metode eksperimen dengan cara koagulasi-flokulasi dan secara biologi menggunakan bantuan dari tanaman kayu apu (Pistia stratiotes L.).Tujuan dari penelitian ini untuk mengetahui cara pengolahan yang efektif dalam menjernihkan limbah cair domestik pada sungai dan mengetahui kadar $\mathrm{pH}$ yang terkandung di dalam air limbah. Dari penelitian yang sudah dilakukan menghasilkan air yang jernih dan $\mathrm{pH}$ yang normal yang terdapat pada air sungai dengan menggunakan kayu apu. Luaran dari penelitian ini adalah menjernihan air dan memberitahu masyarakat desa ketapangtelu untuk mengetahui manfaat kayu apu dalam limbah cair domestik, alternatif pengolahan limbah cair domestik yang mudah dan murah untuk mengurangi banyaknya pencemaran air,mendapatkan hasil air yang jernih dengan kadar $\mathrm{pH}$ normal.
\end{abstract}

Kata kunci : limbah cair domestik, koagulansi-flokulasi, kayu apu (Pistiastratiotes L.).

\section{LATAR BELAKANG}

Permasalahan lingkungan saat ini yang dominan adalah limbah cair yang berasal dari hasil kegiatan rumah tangga dan industri. Limbah cair yang tidak dikelola akan menimbulkan dampak pada perairan. Air menjadi masalah yang perlu mendapat perhatian yang seksama dan cermat. Karena untuk mendapatkan air yang bersih, sesuai dengan standar tertentu, saat ini menjadi barang yang mahal karena air sudah banyak tercemar oleh bermacam-macam limbah dari hasil kegiatan manusia, baik limbah dari kegiatan rumah tangga, limbah dari kegiatan industri dan kegiatan-kegiatan lainnya. Ketergantungan manusia terhadap air pun semakin besar sejalan dengan perkembangan penduduk yang semakin meningkat. Limbah cair domestik yang merupakan air buangan rumah tangga sangat berpotensi menjadi salah satu sumber air yang baru. Pengolahan limbah cair untuk penggunaan ulang dapat mengurangi tingkat pencemaran lingkungan yang disebabkan oleh limbah cair domestik, serta mempromosikan penggunaan limbah cair dari rumah tangga sebagai sumber air bersih yang baru bagi masyarakat.

Limbah cair rumah tangga atau domestik adalah air buangan yang berasal dari penggunaan untuk kebersihan yaitu gabungan limbah dapur, kamar mandi, toilet, cucian, dan sebagainya (Puji dan Nur Rahmi, 2009). Komposisi limbah cair rata-rata mengandung bahan organik dan senyawa mineral yang berasal dari sisa makanan, urin, dan sabun. Sebagian limbah rumah tangga berbentuk suspensi, lainnya dalam bentuk bahan terlarut. Di kota besar misalnya, beban organik (organic load) limbah cair domestik dapat mencapai sekitar $70 \%$ dari beban organik total limbah cair yang ada dikota tersebut. Limbah cair rumah tangga memiliki karakteristik yaitu TSS 25-183 mg/l, COD 100-700 mg/l, BOD 47-466 mg/l, Total 
Coliforms 56 - 8,03x107 CFU/100 ml (Li, 2009).

Tepatnya pada Desa Ketapangtelu Kecamatan Karangbinangun kebiasaan masyarakat yang masih membuang air sisa kegiatan rumah tangga dan belum mengerti akan pentingnya dampak dan bahaya yang ditimbulkan oleh limbah cair domestik tersebut. Faktanya, warga di desa ketapangtelu sudah memiliki saluran air buangan untuk limbah cair domestik tapi mereka tidak menggunakan dengan semestinya. Mereka lebih memilih membuang air limbah domestik ke sungai karena menurut mereka lebih efisien.

Dari latar belakang tersebut maka diadakan penelitian perbandingan uji coba zat pencemar yang ada di dalam air sungai tersebut. Metode yang digunakan adalah koagulasi-flokulasi dan secara biologi menggunakan bantuan dari tanaman kayu apu (Pistia stratiotes L.) yang tumbuh subur di sungai. Penelitian ini membandingkan hasil antara uji coba secara kimia dan biologi. Dari hasil ini diharapkan limbah cair hasil pengolahan dapat memenuhi baku mutu limbah cair dalam beberapa parameter yang diamati sehingga air bisa kembali normal.

\section{METODE PENELITIAN}

Metode yang digunakan adalah metode eksperimen dengan cara koagulasi-flokulasi dan secara biologi menggunakan bantuan dari tanaman kayu apu (Pistia stratiotes L.).

\section{Desain}

Penelitian yang dilakukan menggunakan sampel air limbah cair dari sungai desa ketapangtelu untuk dilakukan perbandingan pengolahan air limbah secara biologi dan kimia menggunakan metode eksperimen.

\section{Pelaksana penelitian}

Uji coba secara kimia :

a. Mengambil sampel air

b. Menyiapkan botol plastik

c. Menimbang tawas dan kapur sesuai dengan takaran

d. Menuangkan air limbah domestik kedalam botol plastik

e. Campurkan dengan kapur,pasir dan kerikil

f. Kemudian masukkan tawas dan aduk secara cepat

g. Selanjutnya, air limbah dialirkan ke empat bak pengaduk lambat untuk proses flokulasi serta ditambahkan polimer untuk memperbesar ukuran flock. h. Setelah melalui proses flokulasi, air limbah dialirkan keempat pengaduk lambat, air hasil olahannya dialirkan pada bak netralisasi. Air olahan dari bak filtrasi ini merupakan air bersih hasil uji coba, sedangkan endapan dialirkan ke bak pengering lumpur.

Uji coba secara biologi :

a. Mengambil sampel air

b. Menyiapkan botol plastik

c. Menyiapkan kayu apu

d. Menyiapkan kerikil dan pasir

e. Menuangkan air limbah domestik kedalam botol plastik

f. Menunggu proses dari kayu apu untuk menyerap zat pencemar membutuhkan waktu sedikit lama karena membutuhkan proses alam.

g. Selanjutnya, air limbah cair domestik dialirkan ke bak penampung yang berisi pasir dan kerikil guna proses sedimentasi secara alamiah.

h. Pengujian $\mathrm{Ph}$ sampai ph normal.

i. Air bisa digunakan kembali.

\section{Teknik Pengumpulan dan Analisis Data}

Penelitian ini dimulai dengan pengambilan data primer yaitu dengan cara observasi langsung ke lapangan untuk melakukan uji coba perbandingan antara pengolahan limbah cair domestik menggunakan metode kimia dan biologi. Analisis data penelitian ini peneliti menggunakan teknik rancangan percobaan secara berulang dengan dua metode yang digunakan secara biologi dengan memanfaatkan tanaman kayu apu (Pistia stratiotes L) dan secara kimia menggunakan koagulan-flokulasi dengan cara mengambil data langsung ke lapangan untuk menganalisis sampel air sungai tentang zat pencemar yang terkandung di air sungai tersebut dan cara pengolahan limbah cair.

\section{HASIL DAN PEMBAHASAN}

Penelitian yang dilakukan yaitu proses pengolahan limbah cair domestik menggunakan metodekoagulasi-flokulasi dan fitoremidiasi menggunakan tanaman kayu apu (Pistiastratiotes L.)Pada metode koagulasi-flokulasi koagulan yang digunakan ialah koagulan tawas dan fitoremidiasi yang digunakan ialah tanaman kayu apudengan airyang diuji adalah air limbah deterjen, air sungai dan air sumur. Dengan parameter yang dianalisis ialah tingkat kejernihan dan $\mathrm{pH}$. 
Table 1. Pengujian $\mathrm{pH}$ sebelum dan sesudah perlakuan

\begin{tabular}{|c|c|c|}
\hline Jenis air & $\begin{array}{c}\text { pH } \\
\text { awal }\end{array}$ & $\begin{array}{c}\text { pH } \\
\text { Akhir }\end{array}$ \\
\hline Air sumur & 7,03 & \\
\hline Air sumur + Tawas 5mg & & 4,35 \\
\hline Air sumur + Tawas 10mg & & 4,75 \\
\hline Air sumur + Tawas 15mg & & 4,90 \\
\hline Air sumur + Kayu apu 1 & & 6,56 \\
\hline Air sumur + Kayu apu 2 & & 6,40 \\
\hline Air sumur + Kayu apu 3 & 6,28 & 6,37 \\
\hline Air sungai + Tawas 5mg & & 4,94 \\
\hline Air sungai + Tawas 10mg & & 4,99 \\
\hline Air sungai + Tawas 15mg & & 5,15 \\
\hline Air sungai + Kayu apu 1 & & 7,28 \\
\hline Air sungai + Kayu apu 2 & & 7,25 \\
\hline Air sungai + Kayu apu 3 & & 7,22 \\
\hline Air cucian & 8,00 & \\
\hline Air cucian + Kayu apu 1 & & 7,10 \\
\hline Air cucian + Kayu apu 2 & & 7,15 \\
\hline Air cucian + Kayu apu 3 & & 7,12 \\
\hline Air cucian + Tawas 5mg & & 4,05 \\
\hline Air cucian + Tawas 10mg & & 4,00 \\
\hline Air cucian + Tawas 15mg & & 3,90 \\
\hline
\end{tabular}

Dari hasil pengujian diperoleh data yang menunjukkan bahwa pengaruh tawas dan kayu apu terhadap 3 perlakuan yang diuji cobakan tergantung konsentrasi tawas dan kayu apu yang diberikan pada masing-masing pengulangan. Dari ketiga perlakuan pada masing-masing pengulangan tidak semuanya sama, dari table pengujian ph didapat air yang jernih adalah air sungai yang menggunakan kayu apu.

Tabel 2. Hasil Pengamatan terhadap Tingkat Kekeruhan Air

\begin{tabular}{|c|c|c|c|}
\hline $\begin{array}{c}\text { Bahan yang } \\
\text { digunakan }\end{array}$ & $\begin{array}{c}\text { Air } \\
\text { sungai }\end{array}$ & $\begin{array}{c}\text { Air } \\
\text { sumur }\end{array}$ & $\begin{array}{c}\text { Air } \\
\text { cucian }\end{array}$ \\
\hline Tawas+kapur 5mg & 1 & 2 & 4 \\
\hline $\begin{array}{c}\text { Tawas+kapur } \\
\text { 10mg }\end{array}$ & 3 & 2 & 3 \\
\hline $\begin{array}{c}\text { Tawas + kapur } \\
\text { 15mg }\end{array}$ & 2 & 2 & 2 \\
\hline Kayu apu 1+pasir & 1 & 4 & 4 \\
\hline Kayu apu 2+pasir & 1 & 4 & 4 \\
\hline Kayu apu 3+pasir & 1 & 4 & 4 \\
\hline
\end{tabular}

\section{Keterangan :}

Jernih $=1$

Agak keruh $=2$

Keruh $=3$

Sangat keruh $=4$
Tabel 3. Hasil Analisis Data

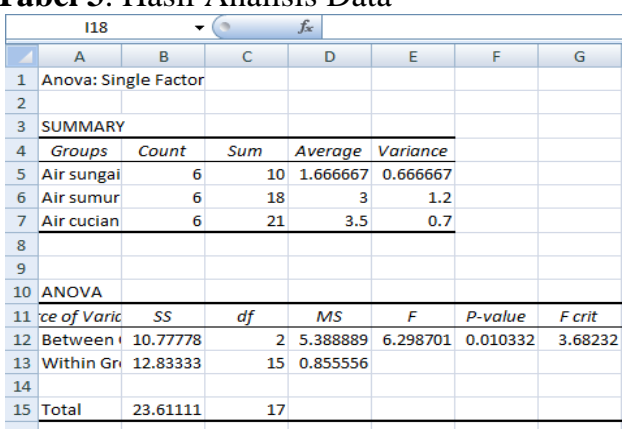

Karena $\mathrm{F}=6,298>\mathrm{F}$ tabel $=3,34$ maka Ho ditolak. Dengan demikian, dapat disimpulkan bahwa rata-rata 3 perlakuan pada masingmasing ulangan berpengaruh secara signifikan.

Pada tabel 1 membahas tentang pengujian ph awal sebelum perlakuan dengan menggunakan 3 perlakuan yaitu air sumur,air sungai dan air cucian. Hasil dari pengujian tersebut menghasilkan urutan ph yang normal terdapat air sumur.

Pada tabel 2 membahas tentang pengujian ph akhir setelah perlakuan. Dari 18 ulangan ph yang mendekati netral terdapat pada air sungai dengan menggunakan kayu apu 3 sebesar 7,22 sedangkan ph terendah terdapat pada air cucian dengan menggunakan tawas $15 \mathrm{mg}$ sebesar 3,90.

Pada tabel 3 data hasil pengamatan tingkat kejernihan air. Air yang paling jernih terdapat pada air sungai dengan menggunakan kayu apu sedangkan air yang sangat keruh terdapat pada air sumur dan air cucian yang menggunakan kayu apu. Pada perhitungan hasil analisis data menggunakan anova single factor didapat data yang menunjukkan bahwa $\mathrm{F}=6,298>\mathrm{F}$ tabel $=$ 3,34 maka Ho ditolak. Dengan demikian, dapat disimpulkan bahwa rata-rata 3 perlakuan pada masing-masing ulangan berpengaruh secara signifikan.

\section{KESIMPULAN}

Proses pengolahan limbah cair domestik dengan metode sederhana yakni koagulasi-flokulasi dan fitoremidiasi tanaman kayu apu dapat menguragi pencemaran pada air. Penjernihan menggunakan proses pengolahan secara kimia dan biologi dengan 3 perlakuan dan 3 pengulangan. Setelah dilakukan proses sesuai prosedur dan diukur ph maka diperoleh air yang paling jernih adalah air sungai dengan menggunakan kayu apu. 


\section{DAFTAR PUSTAKA}

Agusetyadevy, Imbar, dkk. 2013. Fitoremediasi Limbah yang Mengandung Timbal $(\mathrm{Pb})$ dan Kromium $(\mathrm{Cr})$ dengan Menggunakan Kayu Apu (Pistia stratiotes L).Yogyakarta :Jurnal

Budi, P 2014,Konsep Dasar Penilaian Properti. BPFE : Yogyakarta.

Jurnal Penelitian Pemukiman 13 (1): 34-42. Wardhana, W.A. 2000. Dampak Pencemaran Lingkungan. Yogyakarta: Andi Offset.

P. Nugro R., "Proses Pengolahan Limbah Cair Domestik", Majalah "Teknologi Untuk Negeri I”, BPPT, Jakarta, 2003.

Prayogo,T.,Budiman, B.,2009, Survei Potensi Pasir Kuarsa di Daerah Ketapang Propinsi Kalimantan Barat, Jurnal Sains Dan Teknologi Indonesia, Vol. 11, No. 2,hal.126-132

Puji dan Nur Rahmi. 2009. Pengolahan Limbah Cair Domestik Menggunakan Lumpur Aktif Proses Anaerob. Universitas Diponegoro, Fakultas Teknik. Semarang. (Skripsi).

Putra, Sugili, dkk. 2009. Optimasi Tawas Dan Kapur Untuk Koagulasi Air Keruh Dengan Penanda I-131. Dalam PROSIDING SEMINAR NASIONAL V SDM TEKNOLOGI NUKLIR ISSN 19780176. Yogyakarta.

Ridhowati, sherly. 2013. Mengenal Pencemaran Ragam Logam, Yogyakarta: Graha Ilmu. Edisi Pertama.

Sugiharto. 2008. Dasar-dasar Pengelolaan Air Limbah. Penerbit Universitas Indonesia. Jakarta

Tjokrokusumo. 1995. Pengantar Konsep Teknologi Bersih Khusus Pengelolaan dan Pengolahan Air. STTL "YLH". Yogyakarta

Wolverton, dan Mcknown, 2004, Pistia stratiotes L. untuk menghilangkan fenol dari air yang tercemar, Journal Aquatic Botany (10): 72721 